\title{
Optimization of Emprit Ginger Oil Yield through Operating Temperature with Microwave Ultrasonic Steam Diffusion Method
}

\author{
Irfiani Nurul $^{1}{ }^{*}$, Gilang Maulana Alif ${ }^{1}$, Fikaputri Rohmatul $^{1}$, Zel Andesra $^{1}$ \\ ${ }^{1}$ Vocation, Industrial Chemical Engineering, Sepuluh Nopember Institute of Technology, Surabaya \\ Email: ${ }^{*}$ irfiani.nurul.mawaddah@gmail.com
}

Received: 2021-10-22 Received in revised from 2021-10-26 Accepted: 2022-01-05

\begin{abstract}
Abstrak
Minyak atsiri jahe (zingiberene oil $\left.\left(\mathrm{C}_{15} \mathrm{H}_{24}\right)\right)$ merupakan salah satu produk diversifikasi yang mempunyai nilai jual tinggi. Produk atsiri jahe yang ada dipasar belum memenuhi standar produk ekspor, berdasarkan standar Essential Oil Association of USA (EOA). Rendahnya kualitas minyak atsiri jahe ini disebabkan proses produksinya dengan penyulingan konvensional. Metode ini paling sering digunakan karena mudah dioperasikan dan menghasilkan produk yang cukup baik namun membutuhkan waktu lama. Metode ektraksi lain yang dikembangkan adalah Microwave Distillation and Simultaneous Solid-Phase Microexctraction (MDSS- PM). Pada metode ini waktu yang dibutuhkan lebih cepat namun produk yang dihasilkan tidak sebaik produk Hydrodistillation dan membutuhkan energi tinggi. Pada penelitian ini dilakukan proses ekstraksi jahe dengan metode Microwave Distillation yang dimodifikasi dengan rekayasa penambahan ultrasonic (MUSDf). Variabel yang digunakan dalam penelitian ini ialah metode Steam Diffusion (SDf), Microwave Exctraction (ME), Microwave Steam Diffusion (MSDf), Microwave Ultrasonic Steam Diffusion (MUSDf) dengan waktu ekstarksi 30, 50, 70, 90 dan 110 menit serta temperature ekstraksi dengan variasi suhu 90, 95, 100 dan 105 0C. Dari hasil penelitian yang telah dilakukan, didapatkan bahwa metode yang terbaik untuk menghasilkan ekstrak minyak jahe adalah dengan menggunakan metode MUSDf dengan yield sebesar 0,952\%, kadar zingiberene sebesar 6,38\%, dan biaya per gram minyak sebesar Rp 17.964.
\end{abstract}

Kata kunci: Hydrodistilation, Jahe Emprit, Minyak Atsiri, MUSDf, zingiberene

\begin{abstract}
Essential oil of ginger (zingiberene oil $\left(\mathrm{C}_{15} \mathrm{H}_{24}\right)$ ) is one of the diversified products that have high selling value. Most of the essential ginger products available in the market haven't allow the standard export products, based on the Essential Oil Association of USA (EOA) standards. The low quality of ginger essential oil products is due to its production process with conventional distillation. This method is most often used because it is easy to operate and produce a good enough product but takes a long time. Another extract method developed is Microwave Distillation and Simultaneous SolidPhase Microexctraction (MDSS- PM). In this method the time required is faster but the resulting product is not as good as Hydrodistillation product and requires high energy. In this research, ginger extraction process using Microwave Distillation method is modified by ultrasonic addition technique (MUSDf). The variables used in this research are Steam Diffusion (SDF) method, Microwave Exctraction (ME), Microwave Steam Diffusion (MSDf), Microwave Ultrasonic Steam Diffusion (MUSDf) with 30, 50,70, 90 and 110 minutes extension time and extraction temperature variations of 90, 95, 100 and 1050C. From the result of the research, it is found that the best method to produce ginger oil extract is by using MUSDf method with yield of $0.952 \%$, zingiberene level is $6.38 \%$, and the cost per gram of oil is $\mathrm{Rp} 17,964$.
\end{abstract}

Keywords: Essential Oil; Ginger; Hydrodistilation; MUSDf; Zingiberene 


\section{Introduction}

Ginger is one of the largest commodities in Indonesia. The amount of ginger production in Indonesia always increases every year. Based on data from BPS (Central Statistics Agency), ginger production in Indonesia in 2020 reached \pm 183 million $\mathrm{kg}$, the highest number compared to other spices such as galangal and ginger. Ginger has many health benefits such as treating rheumatism, impotence, stones, dizziness, colds, and so on. Ginger marketing is generally sold directly per seed or processed in powder form because the price is relatively cheap. However, the use of powdered ginger is limited to consumption.

Ginger also contains essential oils, also known as etheric oil (zingiberene oil) which is widely used in food production, perfume chemical industry and traditional oriental medicine [1]. Essential oils are volatile oils consisting of a mixture of volatile substances with different compositions and boiling points. Ginger essential oil has a good market share. Ginger oil has a fairly high value in the global market. The price of ginger oil currently reaches IDR 500,000 - 600,000/kg in the world. Meanwhile, if Ginger is sold directly, it only costs IDR $2000 / \mathrm{kg}-3000 / \mathrm{kg}$. This is far from the income of farmers if sold directly. The price of ginger essential oil is determined by the quantity and quality of the components of the type of essential oil produced. Ginger essential oil contains Zingiberene which has a distinctive smell of ginger, so it can be processed into other products such as balm, aromatherapy, antihangover, topical oil and so on which are useful for treating nausea, vomiting, stimulating appetite, and helping to expel intestinal gas and helping heart function.

Extraction of essential oils from a material using the extraction method. Various methods and methods for extracting essential oil from ginger rhizome have been widely used. [1], used Hydrodistillation and Supercritical $\mathrm{CO}_{2}$ methods to extract ginger (Zingiber officinale R) essential oil. Hydrodistillation is a method with the process and equipment used is quite simple and quite practical. However, this method has drawbacks, namely it requires a long extraction time, uses a lot of energy, and volatile compounds also have the potential to be lost during the extraction process. Then the Supercritical Fluid Extraction (SFE) method was developed with $\mathrm{CO}_{2}$ as solvent which was used to extract dry ginger. This method can minimize the extraction time, reduce the use of solvents, $\mathrm{CO}_{2}$ is non-toxic and environmentally friendly. However, this method has the disadvantage that the equipment used is expensive with limited application. To cover the shortcomings of the Hydrodistillation and Supercritical $\mathrm{CO}_{2}$ methods, a method was developed, namely Microwave Extraction (ME).

Paisooksantivatana \& Bua-in, extracted Zingiber montanum using the ME method [2]. The advantages of Microwave Extraction are the use of solvents and lower extraction time, but low extraction efficiency and relatively long extraction time. Then the Microwave Distillation and Simultaneous SolidPhase Microextraction (MDSS-PM) method was developed. [3], used the MDSS-PM method to extract ginger (Zingiber officinale) essential oil. The advantages of MDSS-PM are fast extraction time and do not use solvents, but the application of this method is limited. [4] in patent CN102676299A, the lavender oil extraction process was carried out using the Ultrasonic Steam Extraction method. This method produces more lavender oil extract, which is twice the extraction using conventional steam distillation methods and the time required is faster, but the energy used is still quite large. In a study conducted by [4] with the Ultrasonic Steam Extraction method will be used as a reference for the innovative ginger oil extraction method to obtain a more efficient extraction process with less energy and produce high yields with good quality.

Therefore, it is necessary to carry out further research on ginger oil extraction using the Steam Diffusion (SDf), Microwave Extraction (ME), Microwave Steam Diffusion (MSDf) and Microwave Distillation and Simultaneous Solid-Phase Microextraction (MDSS-PM) methods with the addition of electromagnetic waves. ultrasonic to get a more efficient process with less energy and produce high yields with good quality. By processing emprit ginger into ginger oil, it is expected to be a solution to increase the income of the Indonesian people.

\section{Method}

\section{Materials and tools}

The materials used in this study were emprit ginger (Zingiber officinale) and aquades. 
The tools used in this research are condenser, microwave, steam generator, thermocouple, ultrasonic sonotrode, and tools made of glass.

\section{Raw Material Pre-Treatment}

Small white ginger rhizomes cleaned of dirt and cut. This is because impurities such as soil slow down the heating process and do not contain ginger oil. Then placed on a tray so that the drying of the ginger rhizome can be evenly distributed. The tray containing the ginger rhizome was put in an oven to dry for 12 hours at $80^{\circ} \mathrm{C}$ with a pressure of $1 \mathrm{~atm}$. This drying aims to remove the moisture content to the maximum. The ginger rhizome that has been in the oven is then weighed to get the dry ginger rhizome mass.

\section{Ginger Oil Extraction with Steam Diffusion (SDf) Method}

Entering 70 grams of dried ginger rhizome into a 3 neck flask and adding $500 \mathrm{ml}$ of distilled water. Then put the 3 neck flask containing the sample into the microwave and activate the steam generator. Microwave works as a place and without turning it on. Then a steam generator that functions as a heater, solvent supplier, and carries ginger oil that cannot be lifted or condensed. The oil extraction process uses a temperature of $100^{\circ} \mathrm{C}$ and a pressure of $1 \mathrm{~atm}$. Lasts a maximum of 50 minutes which aims to prevent damage to the tool due to overheating.

\section{Ginger Oil Extraction with Microwave Extraction (ME) Method}

Entering 70 grams of dried ginger rhizome into a 3 neck flask and adding $500 \mathrm{ml}$ of distilled water. Then put the 3 neck flask containing the sample into the microwave and activate the steam generator. The oil extraction process uses a temperature of $100^{\circ} \mathrm{C}$ and a pressure of $1 \mathrm{~atm}$.

\section{Ginger Oil Extraction with Microwave Steam Diffusion (MSDf) Method}

Entering 70 grams of dried ginger rhizome into a 3 neck flask and adding $500 \mathrm{ml}$ of distilled water. Then put the 3 neck flask containing the sample into the microwave and activate the steam generator. The oil extraction process uses a temperature of $90-100^{\circ} \mathrm{C}$ and a pressure of $1 \mathrm{~atm}$. Lasts a maximum of 50 minutes which aims to prevent damage to the tool due to overheating.

\section{Ginger Oil Extraction with Microwave Ultrasonic Steam Diffusion (MUSDf) Method}

Entering 70 grams of dried ginger rhizome into a 3 neck flask and adding $500 \mathrm{ml}$ of distilled water. The neck flask 3 which already contains ginger rhizome and aquades is then macerated with an ultrasonic device that functions to help break down the ginger cell walls to speed up the oil extraction process. This process is operated for 30 minutes with a frequency of $30 \mathrm{kHz}$. Then put the 3 neck flask containing the sample into the microwave and activate the steam generator.

\section{Ginger Oil Calculation Analysis}

Yield is defined as the mass of the obtained oil yield component divided by the mass of dry raw materials. From the methods of Steam Diffusion (SDf), Microwave Extraction (ME), Microwave Steam Diffusion (MSDf) and Microwave Ultrasonic Steam Diffusion (MUSDf) the yields obtained will be compared.

Yield calculation formula as equation 1:

$$
\text { Yield }=\frac{\text { Mass_oil_obtained }}{\text { Mass_of_feedstock }} \times 100 \%
$$

\section{Energy Consumption Analysis}

To determine the economic value of the two methods, it is not only seen in terms of the yield produced and the level of extract obtained. But it is also necessary to calculate the energy required during the process.

Equation 2 is a calculation of energy consumption for the MUSDf and MSDf methods: 


$$
\text { Energi_Consumption }=\text { Power } \times \text { Extraction_Time }
$$

\section{Analysis of Ginger Oil Content with GC-MS}

To determine the composition of ginger oil produced from these two methods, quantitative analysis using GC-MS was carried out so that the content of pure Zingeberen oil could be known. Analysis of ginger oil content using the GC-MS method was carried out at the Testing Service Unit (ULP) of the Faculty of Pharmacy, Airlangga University.

\section{Result and Discussion}

\section{Analysis of the Effect of SDf, ME, MSDf, and MUSDf Methods on Yield}

From the extraction results using the SDf, ME, MSDf, and MUSDf methods with extraction times of 30, 50, 70, 90, and 110 minutes, the yield of ginger oil is shown in Graph 1. Yield is the quotient between the oil obtained and the raw materials used.

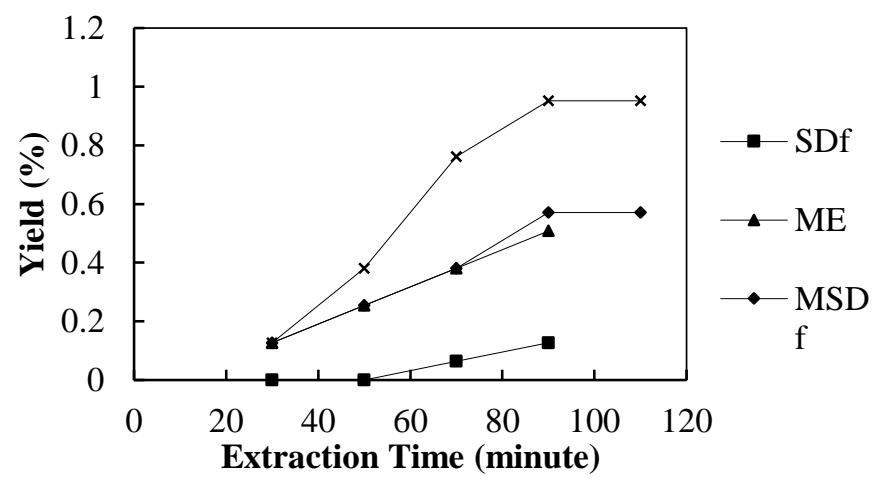

Figure 1. Yield Results of Emprit Ginger Oil Using SDf, ME, MSDf, and MUSDf Methods with Extraction Time

Figure 1 shows that the 90 Minute ginger oil extraction process using the SDf, ME, MSDf, and MUSDf methods resulted in yields of $0.127 \%, 0.508 \%, 0.571 \%$, and $0.952 \%$, respectively. Based on Figure 1, it can be seen that the extraction method using microwave heating produces better yields than extraction with conventional heating.

According to Issartier [5], microwave heating has advantages in extracting essential oils including easy to use, fast process performance accompanied by more effective heating, has a fast response to heat control, and increases production all of which contribute to reducing costs and environmental impact.

Methods with microwave heating, namely ME, MSDf, and MUSDf have some differences in their operating conditions. The difference between the ME method and the MSDf method is the addition of steam to the MSDf method. However, the addition of this steam does not significantly affect the yield of the oil produced. Then for the MSDf and MUSDf methods there is a difference, namely the addition of ultrasonic waves at the maceration stage between the material and the solvent.

The MUSDf method produces higher oil yields than the other three methods. In addition, if the MUSDf method is compared with MSDf, it will produce higher yields of $0.952 \%$ and $0.571 \%$ with an extraction time of 90 minutes. These results explain that the MUSDf method produces a higher yield than the MSDf method at the same time.

Based on Figure 1, it can be seen that the optimum extraction time for the MDSf and MUSDf methods is 90 minutes. From the optimum time of the two methods, it can be concluded that the MUSDf method can increase the yield up to $40 \%$ compared to the MSDf method.

The increase in yield in the MUSDf method is due to the addition of ultrasonic waves at the maceration stage. Ultrasonic power in chemical processes is not directly in contact with the field in question, but through an intermediary medium in the form of water. Sound waves generated by electric power (through the transducer), are transmitted by the liquid medium to the target field through the 
phenomenon of cavitation. The phenomenon of cavitation is the formation of small bubbles in the intermediate medium, which over time the bubbles will increase in size and eventually burst or collapse and release great energy. This energy is used for chemical processes. The process of forming cavitation bubbles to cause the surface of the plant material to break can be seen in Graph 1.

This explanation is in accordance with the research conducted by Khan [6] regarding the extraction of polyphenols from orange peels using the Ultrasound-Assisted Extraction method. From the results of these studies, it is stated that the extraction of bioactive compounds using the help of ultrasonic wave radiation can reduce the extraction time to be shorter. This is because during the sonification process, the cavitation process causes the cell membrane or cell wall to break which allows the diffusion rate to be higher.

Based on research by Liu [7], the application of ultrasonic has several advantages including reducing the solvent used and speeding up the extraction process compared to conventional extraction. In addition, this ultrasonic method is safer, shorter, and suitable for the extraction of thermolabile compounds.

\section{Analysis of the Effect of Extraction Temperature on Yield on MSDf and MUSDf Methods}

In Table 1, the extraction temperature variables are $90,95,100$, and $105^{\circ} \mathrm{C}$. From the extraction results using the MSDf and MUSDf methods with the extraction temperature variable, ginger oil yields were obtained.

Table 1 Yield Results of Small White Ginger Oil Using MSDf and MUSDf Methods with Variable Extraction Temperature

\begin{tabular}{ccc} 
& Temperature & \\
\cline { 2 - 3 } Temperature & Yield $(\%)$ & \\
Extraction $\left({ }^{\circ} \mathbf{C}\right)$ & MSDf & MUSDf \\
& & 0 \\
\hline 90 & 0 & 0,127 \\
95 & 0,127 & 0,952 \\
100 & 0,571 & 0,381 \\
105 & 0,254 & \\
\hline
\end{tabular}

Table 1 shows that the extraction yield for 90 minutes with the MSDf and MUSDf methods at $90 \mathrm{oC}$ extraction temperature is $0 \%$. In the extraction process using the MSDf and MUSDf methods at an extraction temperature of $95^{\circ} \mathrm{C}$ for 90 minutes, the yields were $0.254 \%$ and $0.127 \%$, respectively. In the extraction process using the MSDf and MUSDf methods at the extraction temperature conditions of $100^{\circ} \mathrm{C}$ for 90 minutes, the yields were $0.571 \%$ and $0.952 \%$, respectively. In the extraction process using the MSDf and MUSDf methods at the extraction temperature conditions of $105^{\circ} \mathrm{C}$ for 90 minutes, the yields were $0.254 \%$ and $0.381 \%$, respectively.

\section{Analysis of the Effect of MSDf and MUSDf Methods on the Quality of Ginger Oil}

Analysis of the quality of ginger oil obtained is one of the important determinants to determine a good method for extracting ginger oil. The quality of ginger oil can be determined from various parameters, one of which is the content in ginger oil. To determine the levels of compounds in ginger oil, the Gass Chromatography Mass Spectrometry (GC-MS) test was carried out.

The results of the Zingiberen content in ginger essential oil using the MSDf method were seen to be higher than the MUSDf method. This happens because the MUSDf method adds ultrasonic waves which cause the formation of cavitation bubbles so that it can reduce the reading of the Zingiberene content in the oil. However, the total components of ginger oil identified from the two methods showed that the MUSDf method obtained a higher total component value of $62 \%$ compared to the total component value of the oil using the MSDf method. This is in accordance with the research by Mohd Yusuf, et al., (2016) with the title Physical and Chemical Effects of Acoustic Cavitation in Selected Ultrasonic Cleaning Applications. In his research, it was stated that ultrasonic waves are very good Advanced Oxidation Processes (AOPs) and can cause degradation of compounds. 
Table 2 Results of Quality Analysis of Emprit Ginger Oil Using Gas Chromatography Mass Spectrometry

\begin{tabular}{ccc}
\multicolumn{2}{c}{ (GC-MS) Technique } \\
\hline \multirow{2}{*}{ Compounds } & MSDf & Kadar (\%) \\
\cline { 2 - 3 } & 8,93 & 6,38 \\
\hline Zingiberene & 26,25 & 21,31 \\
Curcumene & 7,72 & 8,59 \\
$\beta$-Bisabolene & 7,92 & 9,42 \\
$\beta$-Sesquiphellandrene & 4,03 & 5,94 \\
Borneol & 45 & 62 \\
Total components identified & &
\end{tabular}

\section{Energy Consumption Analysis Using MSDf and MUSDf Methods}

To determine the economic value of the two methods, it is not only seen in terms of the yield produced and the level of extract obtained. The energy consumption factor needed during the process also needs to be calculated to determine the economic value of the method used. The following is a comparison of energy consumption data between the MSDf and MUSDf methods.

Table 3 Energy Consumption in MSDf and MUSDf Methods

\begin{tabular}{ccc}
\hline Parameter & \multicolumn{3}{c}{ Metode } \\
\cline { 2 - 3 } & MSDf & MUSDf \\
\hline Extraction Time (Minutes) & 110 & 110 \\
Yield (\%) & 0,571 & 0,952 \\
Total input power (Watts) & 2050 & 2070 \\
Energy Consumption (kWh) & 3,075 & 3,105 \\
Cost (Rp/gr oil) & 32.400 & 19.500 \\
\hline
\end{tabular}

From Table 3 it can be concluded that the reduction in the cost of essential oil extraction can be seen in the use of the MUSDf method in terms of energy and yield. With the same time of 110 minutes, the MUSDf procedure produces a yield of $0.952 \%$ while the MSDf produces a yield of $0.571 \%$. The energy required to perform the MUSDf and MSDf methods is $3.105 \mathrm{kWh}$ and $3.075 \mathrm{kWh}$, respectively. So the cost required to obtain 1 gram of ginger oil in the MUSDf and MSDf methods is Rp. 19,500 and Rp. 32,400, respectively.

This explanation shows that the MUSDf method is up to $66 \%$ more cost-effective than the MSDf method. This further confirms that the MUSDf method is better in terms of yield and cost when compared to the MSDf method. In addition, the cost for 1 gram of ginger oil with the MUSDf method is also cheaper than ginger oil in the market, which is Rp. 19,500 and Rp. 56,300.

\section{Conclussion}

The best method to produce ginger oil extract is the Microwave Ultrasonic Steam Diffusion (MUSDf) method because it produces a higher oil yield than the other three methods, namely Steam Diffusion (SDf), Microwave Extraction (ME), and Microwave Steam Diffusion (MSDf) respectively. followed by $0.952 \%, 0.127 \%, 0.508 \%$ and $0.571 \%$. The MUSDf method requires $66 \%$ lower cost per gram than the MSDf method, which is Rp. 19,500 and Rp. 32,500 and the ginger zingiberene oil content of the MUSDf and MSDf methods is relatively the same at $6.38 \%$ and $8.93 \%$, respectively.

\section{Acknowledgments}

The author would like to thank the government through the Ministry of Education and Culture which has funded the 2021 Student Creativity Program (PKM) and to Ir. Agus Surono, M.T. and all parties who have helped the implementation of the entire series of research activities.

\section{Reference}

[1] Mesomo, M. C., Corazza, M. L., Ndiaye, P. M., Santa, O. R., Cardozo, L., \& Scheer,

[2] Paisooksantivatana, Y., \& Bua-in, S. (2009). Essential Oil and Antioxidant Activity of Cassumunar Ginger (Zingiberaceae: Zingiber montanum (Koenig) Link ex Dietr.). Kasetsart J. (Nat. Sci.) 43, 467-475. 
[3] Yu, Y., Huang, T., Yang, B., Liu, X., \& Duan, G. (2007). Development of Gas Chromatographymass Spectrometry with Microwave Distillation and Simultaneous Solid-phase Microextraction for Rapid Determination of Volatile Constituents in Ginger. Journal of Pharmaceutical and Biomedical Analysis, 24-31.

[4] Sansan, Y., Shuangming, L., Xiu, L. W., \& Xiao, X. (2012). Reinforced Extraction Method for Lavender Essential Oil. CN102676299A, 1-7.

[5] Issartier, S. P., Ginies, C., Cravotto, G., \& Chemat, F. (2013). A Comparison of Essential Oils Obtained from Lavandin via Different Extraction Processes: Ultrasound, Microwave, Turbohydrodistillation, Steam and Hydrodistillation. Journal of Chromatography A 1305, 41-47.

[6] Khan, M. K., Vian, M. A., Tixier, A. S., Chemat, F., \& Dangles, O. (2010). Ultrasoun-Assisted Extraction of Polyphenols (Flavanone Glycosides) from Orange (Citrus sinensis L.) Peel. Food Chemistry, 851-858.

[7] Liu, Q. M., Yang, X. M., Zhang, L., \& Majetich, G. (2010). Optimization of Ultrasonic-Assisted Extraction of Chlorogenic Acid from Folium eucommiae and Evaluation of its Antioxidant Activity. Journal of Medicinal Plants Research Vol. 4 (23), 2503-2511. 